\title{
THE EXTENT TO WHICH INSCRIPTIONAL EVIDENCE MAY SERVE AS A SOURCE OF "VULGAR," i.e. SPOKEN LATIN
}

"It is incumbent on Romance scholars to analyze and interpret their exceptionally full stock of linguistic material, using all methods of study at their disposal, working both backward and forward in time. Only thus will Romance linguistics be enabled to do what others expect of it: to serve not only as an end in itself but as a model and training-ground for workers in all fields of historical linguistics." Thus wrote the American scholar, Robert A. Hall, jr. some forty years ago in an essay on the reconstruction of Proto-Romance. ${ }^{1}$ Indeed, the researcher into the history of the Romance languages is faced with, on the one hand, the schemes of reconstruction (essentially based on the principles of the historical comparative method) and the often puzzling testimonies of reality found in the sources. Put in other terms, he has the choice of working with an abstract system represented by starred Latin forms that do not belong to any real language or the reality of the mass of postclassical written records that have come down to us to be analyzed and sifted through with a view to discovering evidences of trends toward Romance in phonology, morpho-syntax, and vocabulary. And while there are, no doubt, materials whose meaning in terms of future evolution of the Romance languages is difficult, if not impossible to discover, there is an abundance of those that prelude the future. It is the attention to the future that, I believe, can give reality and life to the large number of forms collected from inscriptions, late writers, and other sources of so-called "Vulgar", i. e. non-literary Latin.

The schemes of reconstructed Proto-Romance, which could be defined as the earliest stages that can be reconstructed by means of a comparison of all the Romance languages, are not to be thought of as an état de langue, nor to be equated with what is commonly referred to as "Vulgar Latin," unsatisfactory as this term may be because of its vagueness in terms of time reference and social stratifications involved. Since the reconstruction of Proto-Romance can only go back as far as the available Romance data permit, one can at best arrive at an abstract summary of certain characteristics common to all languages, a système d'approchement, to use Meillet's formulation, rather than an historical reality, that is, a living Latin spoken in various regions of the Roman Empire, from which the Romance languages ultimately derive.

The treatment of Latin as a real language in historical Romance studies rather than as an abstract system of relationships has given rise to a great deal of discussion

1 “The Reconstruction of Proto-Romance," Language, 26 (1950), 27. 
and theorizing. It is not my purpose to review the history of the debate. ${ }^{2}$ Suffice it to say that ever since Meyer-Lübke modified his rigid neo-grammarian stance around the turn of the century by substituting a chronologically, socially, and regionally differentiated Volkslatein (the term he preferred to Vulgärlatein) for a reconstructed, homogeneous, and unitary Ursprache existing separately from and independently of literary Latin, Romanists have increasingly come to rely on documentary evidence for explaining Romance developments by searching for the testimonies of a real language rather than on the reconstruction of a lingua etymologica, a kind of reconstructed Romance Latin.

The publication of Hugo Schuchardt's three-volume Vokalismus des Vulgärlateins, ${ }^{3}$ a little over a hundred years ago, marked the beginning of documentary research in the field of Romance philology, the first concerted attempt at sifting out Romance features from non-literary written sources, such as inscriptions, manuscripts, glossaries, and remarks by Latin grammarians. The novelty of the Vokalismus, however, did not merely consist of the linguistic analysis of the direct sources of this non-literary Latin but also in Schuchardt's a priori belief that the sermo plebeius he was dealing with must have been locally differentiated from the earliest times on, though he himself had to admit, albeit reluctantly, that this rustic Latin appeared on all monuments of all regions as essentially the same (Vokalismus I, 77). Thus, he posed one of the fundamental problems that has plagued Vulgar Latin and Romance studies ever since, namely the axiom of a locally differentiated Latin, on the one hand, and, on the other hand, the testimony of postclassical texts that seem to show a unified language with no appreciable local variations. The question, in other words, is the following: do linguistic features that differentiate Romance languages and dialects correspond to dialectal differences already in existence in Latin?

While the thesis of vertically (i. e. socially) and horizontally (i. e. geographically) differentiated Latin has become generally accepted by Romance scholars, it is the degree of regional differences which, in the present state of our knowledge, is still and, presumably, will continue to be a matter of controversy, for there remains the vexing problem of reconciling linguistic differentiation of a living Latin spread over the vast area of the Roman Empire with the evidence of the available written monuments that reveal an essentially uniform Latin, giving little or no clear indication of local variations. Attempts to show the existence of dialectial characteristics pointing to an "African", "Gaulish", "Hispanic", or "Danubian" Latin have not yielded cogent results, the authors who analyzed inscriptional material of a particular region having only been able to cull post-classical phonetic and morpho-syntactic features that could not be considered as being specific to a given region. ${ }^{4}$

2 For a concise summary of the debate, cf. G. Reichenkron, Historische latein-altromanische Grammatik, Wiesbaden, 1965, 58-76.

3 Leipzig, 1866-68.

4 The following classic studies need to be recalled in this connection: Karl Sittl, Die lokalen 
I shall attempt to show, in what follows, the way in which we can utilize inscriptional material as a source of spoken Latin and evidence of its regional differentiation. Let me recall that there is no such thing as a text written in the sermo vulgaris, that is a text in.Vulgar Latin and that the best we can hope for is to find hints and to catch an occasional glimpse of the true nature of the spoken language through inadvertances and unconscious mistakes of the writer since, as Einar Löfstedt reminds us, "even the most uneducated person, as soon as he begins to write, if it be only a letter or a few words on a plastered wall, is directly or indirectly influenced by innumerable literary precedents or reminiscences."

It is generally admitted that private, non-official inscriptions, particularly prose inscriptions of the funerary type, constitute a valuable source of spoken Latin because they frequently deviate from the orthographic and grammatical norms of literary Latin and that many of these deviations are not fortuitous but, indeed, are prompted by spoken language habits that find eventual expression in one or the other Romance language. The validity of Veikko Väänänen's claim, for instance, that the 5,000 Pompeian graffiti "constituent un monument unique de la vie ordinaire" has been proven by the general recognition and critical acclaim of his monograph first published in 1937, now in its third edition. ${ }^{6}$ And once the influence of the spoken language is acknowledged, there is no reason to assume that such an influence should be limited to phenomena that are common to all of Romania, to the exclusion of features that are characteristic of a particular region. Furthermore, seeing that inscriptions are localized and in many instances also dated with some accuracy, they yield information that can only exceptionally be gleaned from literary sources during the early post-classical stages of Latin. To illustrate this point, Gerhard Rohlfs, one of the most thoughtful Romanists of our time, adduces the following example: in inscriptions from southern Italy and Rome (volumes IX and VI of the CIL, respectively) one occasionally comes across the form tata in the meaning of "father". This word, we know, has survived in this regions to this day as the more usual one to designate this member of the family, particularly when speaking of one's own father; thus, in the Calabrian dialect tata oje non vene corresponds to a Latin TATA HODIE NON VENIT. The word tată, also

\footnotetext{
Verschiedenheiten der lateinischen Sprache mit besonderer Berücksichtigung des afrikanischen Lateins (Erlangen, 1882), Jules Pirson, La langue latine des inscriptions de Gaule (Bruxelles, 1901), Albert Carnoy, Le latin d'Espagne d'après les inscriptions (Louvain, ${ }^{2} 1906$ ) and the more recent studies by H. Mihăescu, Limba latină in provinciile dunărene ale Imperiului Roman (Bucarest, 1960) and, in particular, the expanded French version of his book entitled La langue latine dans le Sud-Est de l'Europe (Paris/Bucarest, 1978), as well as Sorin Stati, Limba latină în inscriptiile dîn Dacia şi Scythia Minor (Bucarest, 1961). In fact, summing up his substantial research, the Rumanian scholar concludes that: "Pour nombreux et variés qu'ils soient, les faits linguistiques coservés dans les inscriptions et les textes du sud-est de l'Europe ne sont pas spécifiques pour cette région, ni uniques" (La langue latine, 1978, 327).

5 Late Latin. Oslo, 1959, 15.

$6 \quad$ Le latin vulgaire des inscriptions pompéiennes (3rd ed. Berlin, 1966).
} 
attested on inscriptions from the Danubian Provinces, has replaced Lat. PATER in Romanian altogether. ${ }^{7}$

No one will quarrel with Rohlfs as far as localizing lexical items goes. The problem arises when we want to investigate dialectal differences as they may be reflected in the language in which inscriptions are couched. As Antonio Tovar has pointed out: "there are irregularities in the materials whose meaning in connection with the future evolution of Romance languages is impossible to discover; there are others in which the future annonces itself. Attention to the future is what can vivify the swarm of forms collected from inscriptions, late writers, and the rest of the sources for "Vulgar Latin". If, indeed, misspellings can show important trends toward later Romance developments, then we must ask ourselves just how much value we may attach to "mistakes" due to the negligence or the ignorance of the stonecutter, so as not to read into them more than we are entitled to. We must, thus, guard against drawing hasty conclusions concerning phonological and morphological phenomena, while keeping in mind that an isolated instance of a specific phenomenon may turn out to be significant, such as the lunis die formula found on some Italian and Hispanic epitaphs.

From a philological point of view, inscriptions have not escaped the critis's eye and limitations placed on their value have been pointed out more than once. For one thing, the variety of language is quite restricted and, except for metric inscriptions which are influenced to a large extent by literary and poetic traditions, they very often are made up of little more than traditional formulae, proper names, abbreviations, etc. Yet, even the severest critics admit that with a sufficient body of material it is often possible to cull some interesting information as to the state of the spoken language. ${ }^{9}$ $\mathrm{Be}$ it said in passing that critics of inscriptional material as being valid evidence of the state of the Latin language at a given time, as well as being a source of information concerning specifically local features, have not spurned citing isolated inscriptional examples to support their theories.

Another limitation placed upon the value of inscriptional material which, incidentally, it shares with other documentary evidence, is that certain spellings may not at all represent actual pronunciation but may rather be due to stereotyped orthography, much the way Fr.eau represents the phoneme /o/ in the modern language, while reflecting a former stage of the language.

Granting the shortcomings, limitations, and caveats, I firmly believe that, all things considered, inscriptions, particularly Christian prose inscriptions, are a valid source of spoken Latin, provided we do not draw general conclusions about phonolo-

7 In the languages that form the bridge between Southern Italy and Rumania, the word for "father" derived from Lat. TATA is also attested, e.g., Old Dalmatian tata, tèta, Vegliote tuota, and Albanian tate. Cf. Wilhelm Meyer-Lübke, Romanisches etymologisches Wörterbuch (3rd ed. Heidelberg, 1935), 710 (\#8596).

"A Research Report on Vulgar Latin and its Local Variations," Kratylos, 9 No. 2 (1964), 113-114.

Thus, W. Kroll, "Das afrikanische Latein,” Rheinisches Museum für Philologie, 52 (1897), 573. 
gical and morpho-syntactic phenomena from single occurrences of a "misspelling," but on the basis of the frequency of occurrence of a given orthographic deviation or deviant construction with respect to the classical Latin standard. ${ }^{10}$ Linguistic inquiries into particular regions, having yielded little, if anything, in terms of regional characteristics of spoken Latin, it seemed to me that if we wanted to learn something about such local variations, an important feature of the study of any spoken language, this could only be done so by means of a comparative étude d'ensemble on the language of Roman Italy and its Provinces, such as the one advocated by Sittl nearly a century ago. ${ }^{11}$

Armed with basically two sources, Ernst Diehl's edition of Latin Christian inscriptions $^{12}$ and Vives' collection of Christian inscriptions from Iberia, ${ }^{13}$ I set out, in three separate studies, ${ }^{14}$ to analyze prose inscriptions of the funerary type, with a view to discovering, by means of counting "mistakes" on a given inscription with respect to the classical Latin norm, certain language features occurring more frequently in one or several regions than in others, characteristics which, at the same time, would also suggest trends pointing to future Romance developments. With a corpus of ca. 5,000 items from the Western Roman Empire, 1,250 items from Africa and 300 items from the Latin speaking provinces of the East, ${ }^{15}$ I divided my material into five main regions, following the topographical classification of the Corpus Inscriptionum Latinarum, namely (a) the Iberian Peninsula (further subdivided into Baetica, Lusitania, and Tarraconensis); (b) Gaul (subdivided into Narbonensis and Lugdunensis); (c) Italy (subdivided into Northern, Central, and Southern Italy); (d) Rome (capital of the Ro-

10 Sittl, as a matter of fact, may have well been the first one to realize the importance of frequency when he wrote: "gewisse Lautveränderungen sind vielleicht allen Dialekten einer Sprache gemeinsam, aber der Unterschied besteht dann darin, dass sie in einem äusserst selten, in einem anderen fast regelmässig vorkommen" (Die lokalen Verschidenheiten, 47).

11 "Jahresbericht über Vulgär- und Spätlatein 1884-1890," Jahresbericht über die Fortschritte der classischen Alterthumswissenschaft, 67 (1892), 226. Sittl predicted, as a matter of fact, that once the inscriptional material would be made available through the monumental Corpus Inscriptionum Latinarum - which had barely begun publication in his days - dialectal differences would become quite apparent.

12 Inscriptiones Latinae Christianae Veteres, ed. Ernst Diehl. 3 vols (Berlin, 1924-1931; rpt. 1961) with Supplementum, ed. J. Moreau and H. I. Marrou (Berlin, 1967).

13 Inscripciones cristianas de la España Romana y Visigoda. Barcelona, 1942.

14 Paul A. Gaeng, An Inquiry into Local Variation in Vulgar Latin, as reflected in the Vocalism of Christian Inscriptions (University of North Carolina Stuudies in the Romance Languages and Literatures, No. 77) (Chapel Hill, 1968); A Study of Nominal Inflection in Latin Inscriptions: a Morpho-Syntactic Analysis (UNC Studies in the Romance Languages and Literatures, No. 182) (Chapel Hill, 1977); Collapse and Reorganization of the Latin Nominal Flection, As reflected in Epigraphic Sources (Scripta humanistica) (Potomac [MA], 1984).

15 The paucity of material with respect to the Western Roman Empire and Africa is essentially due to the fact that Christian inscriptions from the Danubian Provinces greatly decrease in number during the fourth century A. D. and are no longer found beyond the end of that century, while in Dalmatia they are still attested in the sixth century. Cf. Ion Fischer, Latina dunăreană (Bucureşti, 1985), 7. 
man world whose separate treatment is justified by the abundance of material); (e) Africa; and (f) the East (subdivided into Dalmatia and the Danubian Provinces). Because of the high percentage of dated material in some areas (40\% of all prose inscriptions in Gaul and Italy, better than $80 \%$ in Iberia, $20 \%$ in Africa, but less than $20 \%$ in the East), I was also able to establish, whenever possible, chronological divisions into, roughly, the fourth, fifth, and sixth centuries. ${ }^{16}$

On the basis of comparative percentage figures obtained whenever the number of examples of a given phenomenon seemed to justify this procedure (e.g., the change from /-um/ to /-o/ in the accusative singular of 2 nd declension nouns, as in the frequent phrase titulo posuit), I was able to show that, despite the strongly formulaic nature of inscriptional material and the fact that deviations from the classical Latin norm appear to be more or less identical in all areas of the Empire, it is possible to detect certain features that occur more frequently in one or several areas as against others, thus pointing to regional differentiations in spoken Latin during the period of latinity covered by the monuments in question.

A few pertinent examples drawn primarily from both phonology and morphosyntax, specifically the nominal flection, may serve to illustate my thesis:

\section{A. PHONOLOGY}

1. We know that in the greater part of Romania Latin $/ \mathbf{1} /$ and $/ \breve{\mathbf{u}} /$ in stressed sylla-

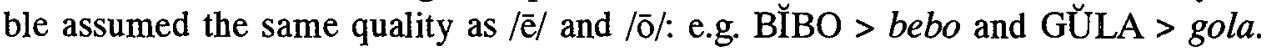
Indeed, inscriptions abound in spellings like menus, veces, tomolo, colomna, fede, etc. reflecting these changes in pronunciation. A statistical analysis shows that, by the fifth century, this phenomenon is particularly pronounced in Gaul. We are also told that the merger of Latin / $/ \overline{\mathrm{e}} /$ and $/ \overline{1} /$ must have preceded that of $/ \overline{\mathrm{o}} /$ and $/ \mathrm{u} /$ by about a century. ${ }^{17}$ Indeed, comparative statistics reveal that (a) the merger of $/ \overline{\mathrm{e}} /$ and $/ \mathbf{1} /$ is particularly pronounced in Gaul and (b) that the merger of $/ \overline{0} /$ and $/ \breve{\mathrm{u}} /$ is not significant before the sixth century, except for the Central Italian area, suggesting that the front vowels did not universally merge before the back vowels, as suggested by accepted theory; ${ }^{18}$

16 The Hungarian scholar, József Herman, proposed a comparative quantitative analysis to epigraphic material in anarticle entitled "Aspect de la différentiation territoriale du latin sous l'Empire." (Bulletin de la Société linguistique de Paris, LX, I(1965), 54-70), in which he compared fifth and sixth century Christian inscriptions from Iberia, Gaul, northern and southern Italy, Rome, and Dalmatia. His methodology, however, differs from mine in that he bases his comparison not on the frequency of deviant spellings with respect to the classical Latin norm, but rather on deviations alone, i. e. on the ratio between spellings that are likely to reflect a phonetic feature of the spoken language in a given region and the total number of all deviations in that same region.

17 Edoua rd Bourciez, Eléments de linguistique romane (44th ed. Paris, 1956), 42-43.

18 This conclusion is confirmed by Herman's comparative study: “Nos matériaux permettent d'apporter un léger correctif à la conception largement répandue selon laquelle le regroupement des timbres dans la série vélaire était plus tardive que celui dans la série palatale." "Essai sur la latinité du littoral adriatique à l'époque de l'Empire," in Sprache und Geschichte. Festschrift für Harri Meier zum 65. 
2. While unstressed Latin vowels in the initial syllable appear to be quite stable, the expected Latin /e/ is frequently spelled with $i$ on Roman inscriptions e.g., difunctus, dipositus for DEFUNCTUS, DEPOSITUS. In fact, the pattern of orthographic $i$ for Lat. / $/$ / in this position with respect to other areas is so consistent that Rome may well be considered as the focal point of this feature which is characteristic of modern standard Italian.

3. The loss of the intertonic vowel, specifically the penult, is responsible for a "phonological rift" between the provinces of Gaul (including the Gallia Cisalpina) and the Iberian Peninsula, on the one hand and the rest of Romania, on the other hand, foreshadowing the eventual difference in syllabic structure of the Gallo- and IberoRomance languages with respect to the Italo- and Balkan-Romance idioms. Frequent spellings like femena, nomene, comete, domene, famola, regola, secolo, etc. gleaned from Iberian, Gaulish and Northern Italian inscriptions, in particular, suggest a lack of stability of the unstressed vowel in this position signaling its weakening into a schwa and subsequent disappearance though syncopy. Inscriptions from Gaul show the highest percentage of incorrect spellings (46,8\% and $55,5 \%$ of $e$ spellings for $/ \mathbf{1} /$ and $70,9 \%$ and $54,4 \%$ of $o$ spelings for / $\mathrm{u} /$ on 6th century inscriptions from Narbonensis and Lugdenensis, respectively) followed by those from Iberia and Northern Italy (with between $10 \%$ and $24 \%$ incorrect spellings), while misspellings in Central and Southern Italy (including Rome), Africa, and the Eastern Provinces (Dalmatia and the Danubian Provinces) are least frequent, never more than $5 \% .{ }^{19}$ What emerges from these data, then, is a cleavage between Centro-Southern Italy, Dalmatia and the Danubian Provinces, on the one hand and the rest of Romania, on the other hand, announcing future Romance developments, i. e. a trend towards a paroxitonic syllable structure in Gallo- and Ibero-Romance - and a subsequent evolution to an oxytonic structure in modern French -, while most Italian dialects, Sardinian, Dalmatian and the only survivor of Eastern Latin, Rumanian, tend to preserve the proparoxytonic structure of Latin, e.g. FEMINA > Fr. femme, Sp. hembra, Port. fêmea, It. femmina, Rom. femeie. ${ }^{20}$

Geburtstag, ed. Eugenio Coseriu and Wolf-Dieter Stempel [München, 1971], 223).

19 Intertonic vowels in African, Dalmatian, and Danubian inscriptions appear to be quite stable. Cf. Stephen W. Omeltchenko, A Quantitative and Comparative Study of the Vocalism of the Latin Inscriptions of North Africa, Britain, Dalmatia, and the Balkans. Chapel Hill, 1977, 206-208 and 304-310.

20 This "macrolinguistic" division does not take account of conservative regions within larger dialectal areas. In northern Italian dialects, for instance, the presence or the absence of syncopy opposes innovative and conservative regions; thus, Lat. TOXICO, gives tosego in Venitian, tosek in Lombardic, and tosk/tözg in Emilian-Romagnolo. Cf. Pavao Tekavčić, "L'épigraphie latine et le problème de la différentiation du latin." Arheološki Vestnik, Vol. XXX, (1979), 564, and Gerhard Rohlfs, Historische Grammatik der italienischen Sprache und ihrer Mundarten. Vol. 1 (Bern, 1949), 227. 


\section{B. NOUN MORPHOLOGY}

The following noteworthy features pointing to regional differentations deserve to be underscored:

1. In the second class of Latin nouns, the /-i/ ending of the genitive singular, when it expresses a possessive relationship, is often replaced by a form in /-o/ on epitaphs from Gaul (particularly the Lugdunensis), Dalmatia and the Danubian Provinces. Thus, we read fili Magno, arca Iucundi puero, Ursiniano subdiacono ossa, etc. An obvious extension of the Latin dative of possession and the dativus sympatheticus, these constructions seem to foreshadow the adnominal dative of Old French and Old Provençal (e.g., li fils le roi), while in Rumanian this construction remains to this day the sole possibility of expressing the possessive genitive. ${ }^{21}$ Attested sporadically on Italian inscriptions, this adnominal construction is totally absent from Iberian inscriptions and we find no traces of it in Ibero-Romance dialects. The use of the possessive and adnominal dative in genitive function in the Latin of the East seems to be, furthermore, confirmed by the substitution of dativ forms in /-i/ for 3rd declension singular genitives in /-is/, as in filius Eufrasio comiti, a dative form that, in all probability, is reflected in the singular of feminine nouns of this declension. ${ }^{22}$

2. A feature which, to my mind, is quite in accord with the development of Italian and Romanian plurals of the $i$ cani, le parti, cinii, parţi type (derived, it would seem, from a Latin form. CANIS, PARTIS rather than class. Lat. CANES, PARTESS) is the marked preference in Italy, Gaul (especially the Lugdunensis area) and the Latin provinces of the East for an /-is/ nominative and accusative ending of $3^{\text {rd }}$ declension nouns (e.g. tres fratris cursoris, parentis dolientis qui superstitis sunt, etc.) while the Iberian and African areas hold on tho the classical Latin /-ës/ ending. Attested on inscriptions and in Latin authors of Republican times (the German Latinist Ferdinand Sommer reports forms like OMNIS, PUPPIS, FINIS, PARTIS from the time of Var$\mathrm{ro}^{23}$ ), this alternative nominative form seems to have spread to the Danubian region as early as the $2^{\text {nd }}$ century A.D., reaching Gaul around the 6 th century, whence its extension in Merovingian Latin. ${ }^{24}$ The evidence culled from inscriptions specifically seems to lead to the conclusion that the plural /-is/ ending was able to assert itself in the popular speech of Italy and the Danubian regions, suggesting, furthermore, a chronological continuity between the /-i/ plurals of Italian and Romanian and the classical Latin accusative of $i$ stems, a theory forcefully advanced by the Romanian scholar Sextil Puşcariu ${ }^{25}$ but generally rejected by theoretical positions that account for these

21 Cf. in this connection the study by Maria Iliescu and Liliane Macarie, "Aspects de l'evolution syntaxique du génitif et du datif en latin tardif." Revue roumaine de linguistique, Vol. 9: 4, 437-444.

22 According to Fischer (Latina dunăreană, 95) this typically Romanian dative case must be attributed to a specific feature of "Danubian" Latin.

23 Handbuch der lateinischen Laut- und Formenlehre (2nd and 3rd eds. Heidelberg, 1948), 382.

24 Cf. Mario Pei, The Language of Eighth-Century Texts in Northern France. New York, 1932, 147.

25 "Une survivance du latin archaïque dans les langues roumaine et italienne," in Mélanges dephilologie 
plurals either through analogical replacement of Lat. /-ēs/ by /-i/ under the influence of the second declension MURI-type plurals or a phonetic development which rests on W. Meyer-Lübke's phonological "law", according to which Lat. /-ës/ > It. /-i/ (e.g., Lat. FLORES > It. fiori $)^{26}$ Excepting the Latin of Gaul, seeing that we are unable to determine the fate of the plural nom./acc. /-is/ ending in the mist that shrouds the passage of this Latin variety to Old French (and the fact that, in principle, all Latin vowels but $/-\mathrm{a} /$ are lost in French anyway), there seems to be ample justification in stating that the regional distribution of the /-es/-/-is/ plural forms generally follows the present-day borderline that separates Italian and Rumanian /-i/ plural isoglosses form the /-es/ plurals of Western Romance languages, specifically Spanish, Portuguese, and Sardinian. ${ }^{27}$

3. In time expressions, the regional distribution of annis/annos (also spelled an$n u s$ ) is an interesting one because it seems to be in harmony with the preceding phenomenon, at least as far as the eventual outcome in the Romance languages goes. In fact, the Central and Southern regions of Italy and the Latin regions of the East, particularly the Danubian Provinces, set themselves apart from Northern Italy, Gaul and Iberia, in that the former show a preference for annis, whereas annos predominates in Gallo- and Ibero-roman regions. Keeping in mind the outcome of Italian and Rumanian masculin plurals in /-i/ after the fall of /-s/ (It. anni and Rum. ani), the choice of annis in most of Italy and the Danubian Provinces is not accidental, confirming $H$. Mihăescu's conclusions to the effect that the prevalence of and preference for the ablative in these regions point to a spoken language phenomenon, namely the trend toward a single plural form in $/-\mathrm{i} / .^{28}$

et d'histoire offerts à Antoine Thomas par ses élèves et ses amis (Paris, 1927), 359-365.

26 Italienische Grammatik. Leipzig, 19890, 60. Indeed, the literature dealing with the problem of 3rd declension plurals in Italian and Rumanian is quite extensive, since all manuals and studies on the historical morphology of these languages make reference to it. A concise summary of the problem is given in Professor Tekavčić's excellent three volume Grammatica storica dell'italiano (Bologna, ${ }^{2}$ 1980, Vol. II 49-51), in which the author also expresses his own theoretical position. Among the essays specifically devoted to this problem, in addition to the one by Puşcariu, the following may be mentioned: Robert L. Politzer, "On the origin of Italian plurals," Romanic Review 43 (1952), 272-281, and "Vulgar Latin -ēs > Italian -i," Italica 28 (1951), 1-5; Paul Aebischer, "La finale -i des pluriels italiens et ses origines," Studi linguistici italiani 2 (1961), 73-111; Francesco Sabatini, "Sull'origine dei plurali italiani: il tipo in -i," Studi linguistici italiani 5 (1965), 5-39; I. Şiadbei, "Persistenţa cazurilor latine in Romania orientală," Mélanges Mario Roques (Paris, 1952), 231-240, and Maria Iliescu, "Notă cu privire la pluralul -i dîn română şi dîn italiană," Analele Universitaţii dîn Craiova (Ştiinţe filologice), 5 (1977), 15-17.

27 Christian inscriptions from Sardinia and few are far between. In order to determine whether there might be any instances of consonant-stem plurals ending in /-is/in inscriptions from this area at all, I have examined the collection edited by Giovanna Sotgiu, Iscrizioni latine della Sardegna (Padova, 1961-1963). I found none.

28 "Cîteva observaţii asupră limbii latine dîn provinciile latine dunărene ale Imperului Roman," Studii şi cercetări lingvistice, 10 : 1 (1959), 89. 
4. A no less interesting feature, which seems to clash with the contemporary state of affairs, is the frequent /-as/ ending for the expected first declension feminine plural in $/-\mathrm{ae} /$ (or /-e/ with the universal reduction of the diphthong) in all areas of Italy (particularly in Rome) and the Latin speaking provinces of the East, as in the oft-quoted inscription from Pannonia: hic quescunt duas matres duas filias numero tres facunt et advenas II parvolas, while being totally absent from Gaulish and Iberian epitaphs. On the other hand, this plural in /-as/ is well represented in Merovingian documents and later Latin documents from Iberia, ${ }^{29}$ which leads to the conclusion that this innovation must have spread from Rome (where the earliest attestations are found), reaching Gaul and Iberia rather late, in any event not before the 7th century. What is interesting about the geographical distribution of this phenomenon is that it is in marked contast with the present-day situation, in that this plural in /-as/ has become characteristic of the Ibero- and Gallo Romance dialects (surviving, however, in Sardinian and in some Northern Italian dialects also ${ }^{30}$ ), whereas the standard Italian, Rumanian and Old Dalmatian feminine plural in /-e/ seems to derive form the classical /-ae/ ending. ${ }^{31}$

Other examples could surely be adduced to support the contention that, despite the formulaic and stereotypic nature of prose inscriptions and the generally identical deviations from the classical Latin norm in all areas of the Roman Empire, it is possible to detect by means of a comparative-quantitative study some significant features that occur in a given area with greater frequency than in another, pointing to regional differences during the period of latinity covered by these documents whose language is closely connected with daily life. There is no denying that, at least in its written form, the Latin language on inscriptions, in texts, and documents of the post-classical period appears as very much the same in all provinces of the Roman world and that, in the absence of a substantial document couched in Vulgar Latin, the best we can hope for is to find certain peculiarities and trends reflecting, more of less clearly, features of the spoken language as they emerge in the various regions of Empire. However imperfect they may be as a source of our knowledge of Vulgar Latin in all its manifestations, inscriptions, I submit, afford the best "glimpse" of certain trends that presage Romance developments.

29 Cf. Mario Pei, Northern France, 137.

30 Cf. Gerhard Rohlfs, Historische Grammatik. Vol. II, 227.

31 The derivation of the Italian and Rumanian feminine plurals in /-e/ is still a matter of controversy. Some scholars have postulated the plural form in/-as/rather than the classical (learned) form in /-ae/ as the origin of Italian and Romanian plurals in /-e/ by way of a phonological process: /-as/ $>$ /-es/ $>$ /-e/, the /-es/stage being attested in early medieval Latin documents from Italy. Cf. in this connection the exhaustive studies by Berengario Gerola, "Il nominativo plurale in -AS nel latino e il plurale romanzo," Symbolae Philologicae Gotoburgenses (Göteborgs Högskolas Årsskrift), 56 (1950), 328-354, and Paul Aebischer, "Le pluriel -as de la première déclinaison latine et ses résultats dans les langues romanes," Zeitschrift für romanische Philologie, 87 (1971), 74-98. 


\section{JEZIK NAPISOV KOT VIR PRIČEVANJA “VULGARNE”, GOVORJENE LATINŠČINE}

Raziskovalec zgodovine romanskih jezikov ima na voljo $\mathrm{z}$ ene strani sheme rekonstrukcije (ki $\mathrm{v}$ bistvu temeljijo na načelih zgodovinske primerjalne metode) in z druge strani nemalokrat kar težko razumljivo pričevanje stvarnosti v dokumentarnem gradivu. Ukvarja se lahko $\mathrm{z}$ abstraktnim sestavom ozvezdenih latinskih oblik, ki ne pripadajo nobenemu resničnemu jeziku, ali s stvarnostjo velike količine ohranjenih poklasičnih pisanih spomenikov, ki jih je treba razčleniti in prerešetati, da bi odkrili dokazila o razvojnih težnjah $v$ smeri proti romanskemu v glasoslovju, oblikoskladnji in besedišču.

Splošno je priznano, da so zasebni, neuradni napisi, zlasti pa prozni napisi pogrebne vsebine, dragocen vir govorjene latinščine, saj kar pogosto kršijo pravopisno in slovnično normo knjižnega jezika. Številna izmed teh odstopanj niso naključna, temveč so jih povzročile navade govorjenja, ki se pozneje odrazijo v tem ali onem romanskem jeziku. Tak dragocen vir so krščanski prozni napisi, predmet te študije. Seveda pa ne smemo izrekati posplošitev o glasoslovnih in oblikoskladenjskih pojavih zgolj na podlagi posamičnih "pravopisnih napak". Jezikoslovne raziskave poedinih predelov latinsko govorečega rimskega sveta so doslej navrgle le malo podatkov o pokrajinskih značilnostih. Te zmore zajeti samo étude d'ensemble, osnovana na opažanjih, kako pogosto neki zapis ali skladenjska zgradba greši zoper klasično knjižno latinščino. 